\title{
KEVIN TIMPE
}

St. Peter's College, University of Oxford

\section{Stewart Goetz. Freedom, Teleology, and Evil (Continuum Studies in Philosophy of Religion). Continuum, 2008.}

Stewart Goetz's Freedom, Teleology, and Evil is an impressive defense of a non-causal libertarian view of free will. Though not without its defenders, noncausal accounts have tended to receive not only considerably less attention than have event-causal or agent-causal views, but also less sympathy. Goetz's book is a formidable challenge to these tendencies and worthy of attention by all those interested in free will.

At the heart of Goetz's view is that free "choices are, first and foremost, explained teleologically in terms of reasons, where reasons are purposes or goals" (p. 3). And it is this same consideration which leads him to reject both event-causal and agent-causal accounts of libertarian freedom. Why think that considerations of teleological explanation lead one to libertarianism in general, as opposed to compatibilism, and to a noncausal libertarian view in particular? The answers to these questions are at the heart of Goetz's book. It is worth noting, however, that Goetz's response to these questions does not exhaust the wealth of insights found in the book. Along the way he also addresses the nature of intentions, the continued debate about Frankfurt-cases and the principle of alternative possibilities, the problem of evil, primal sin, and more. Many of these discussions are quite detailed, and there is no way to do justice to the depth and wealth of Goetz's arguments in a review. But insofar as his treatment of these other issues depends upon what he sees as the relationship between teleology and libertarian freedom, that is where the review will focus.

We may begin by asking why someone might believe that we have libertarian freedom? Unlike Carl Ginet, whose book On Action (Cambridge University Press, 1990) was, prior to Goetz's book, the most developed noncausal libertarian account, Goetz does not base his belief in free will on the phenomenology of choice. Instead, for Goetz such a belief is basic in 'the Plantingian sense': "I am convinced that experiences of choosing, and not other beliefs, ground the belief that I have noncausal libertarian freedom" (p. 4). While Goetz never argues for the existence 
of free will, he does however argue both for incompatibilism and noncausalism. Before turning toward those arguments, it is worth noting that Goetz repeatedly utilizes two main strategies for responding to objections to his central argument. The first is a tu quoque strategy, arguing that if a particular objection against his noncausal libertarian view holds, it also holds against the view held by whomever raises the objection. (He uses this strategy against objections based on Timothy O'Connor's and Randolph Clarke's agent-causal views, as well as against various formulations of the luck objection.) The second strategy is to argue that the objection begs the question against Goetz's own view. (He uses this against Davidson's causalist challenge and, as we shall see below, proponents of Frankfurt-style examples.)

Goetz lays out his own view in chapters one and two. He is primarily concerned with choices, rather than actions, as he takes the former to be the ultimate locus of freedom. (In fact, he later denies that bodily acts can be free, insisting that choices are the only locus of freedom; see pages $80 \mathrm{f}$.) At the heart of his view about free choice is the claim that "a choice is an event that is essentially uncaused and explained teleologically by a reason or purpose" (p. 36). We see here the two central features of Goetz's view: (i) noncausalism and (ii) the centrality of teleology.

Regarding (i), Goetz thinks that choices are simply not the kind of things that can be causally produced. On this issue, the heart of the book is section 2.1 where Goetz outlines the "mental ontological framework" that undergirds the rest of the volume. Here, Goetz differentiates between mental activity and mental passivity, a distinction which is "grounded in the existence of two types of mental properties, namely powers and capacities. These two kinds of properties are inherently different from each other, and each is an ultimate ontological category" (p. 8). Since the nature of exercising a mental power is intrinsically active, such mental actions can have no causes: "any instance or token of mental action by nature lacks an efficient cause" (p. 8). Such exercisings of powers are not only essentially uncaused, but are also ontologically simple and primitive. It would be hard to overestimate the importance of these claims for Goetz's book as a whole. For one, the incompatibility of free will and the truth of causal determinism follows pretty quickly from this ontology: "no exercising of a mental power can be causally determined because no exercise of a mental power can be causally produced" (p. 9). If a choice 
cannot be causally produced, then it cannot be causally determined. This, coupled with the basic belief in free will, generates libertarianism. Furthermore, the same considerations also generate Goetz's commitment to a version of PAP (the principle of alternative possibilities):

An agent has a power to chose, and, whenever he exercises it at a time $t$, he is free at that time to exercise it in a different way. In other words, when an agent is free to make either choice $\mathrm{C} 1$ or $\mathrm{C} 2$, it is not the case that he has one power to choose whose exercising is $\mathrm{C} 1$ and a second power to chose whose exercising is $\mathrm{C} 2$. There is one, and only one, power to choose that can be exercised in only one of two or more incompatible ways. (p. 9)

And many of Goetz's responses to other issues in the contemporary free will debates depend on his non-causal approach.

But is it really this easy to show that exercises of the will (i.e., volitions) are uncaused? Goetz thinks that one "only needs to be aware of his mental act of choosing to know that it is uncaused" (p. 16). He grants in a footnote that "introspection is not the final word" but that it "certainly is, however, the first word" (p. 159, note 24). But why think that this introspection is veridical? How might one attempt to persuade another who didn't have the same introspective experience? There is, unfortunately, little argumentation here other than the ontological distinction mentioned above:

These two kinds of properties [i.e., mental powers and mental capacities] are inherently different from each other and each is an ultimate ontological category. Corresponding to these two kinds of mental properties are two kinds of event, namely an agent's exercising of a mental power and the actualization of a mental capacity in him. (p. 50)

But why not instead think that the actualization of mental capacities can cause the exercising of a mental power? In non-agential examples, it deems that the actualization of capacities causally produces the exercise of powers. Consider, to use a non-agential example, the cell phone sitting here on my desk next to me, which has (among its numerous features) the power to produce a specific ringtone. It currently isn't exercising this power. But if a certain one of its capacities (namely, the capacity to receive a signal from the local cell-tower) is causally activated by an external source, then the phone will ring. So it looks like the exercise of a power 
is not causally distinct from the actualization of a related capacity in all cases. And if this is true of non-agential capacities and powers, then it puts pressure on Goetz's account of agential powers and capacities for whom the exercise of powers is causally independent of capacities. Goetz thinks that agential powers can be exercised without any causal input, including from previous acts of willing. It is for this reason that Goetz thinks there is no reason to adopt an agent-causal approach according to which one has the primitive agent-causal powers to cause acts of will:

What is gained for a libertarian account by postulating a power to cause acts of will (volitions or choices)? Why not just maintain that acts of will are exercising of the power to choose and because they are, they are essentially uncaused? This view is simpler and exemplifies all the virtues of the competing account. (p. 14)

Like van Inwagen and others, Goetz thinks that the addition of agentcausation is "explanatorily superfluous" (p. 4) insofar as it does not secure any further agential control than does the realization that actions are inherently teleological.

This leads us to (ii), the second central element of Goetz's positive view of free will, which is the centrality of teleology. While it is crucial for Goetz that choices are not caused, it is equally crucial that they have teleological explanations. Drawing on work by Donald Davidson, he argues that causal and teleological explanations are fundamentally different and irreducible kinds of explanation. An agent choosing between two actions may have competing reasons for choosing each of these behaviors, but such that "neither reason is sufficient for the occurrence of the relevant choice to act" (p. 19). Goetz grants that the reasons that an agent has may themselves be determined, but denies that that reasons act causally upon the agent. The reasons do not cause the action, but present the agent with a perceived future good to be brought about. So in cases where an agent is torn between two incompatible actions, she is torn between which future good to work towards - that is, she is torn between which reason to respond to. But whichever reason the agent chooses to act on explains the action and prevents it from being random. Goetz argues that sometimes free choices can be given contrastive explanations on his account, though presumably such explanations cannot always be given (as in the case of consciously chosen and reflective akratic actions). 
Goetz's forward-directing account of agential reasons is quite attractive, and relates to - in chapter six - Robert Kane's work on self-forming actions and Michael Bratman's and Robert Nozick's work on life plans.

Chapters three and four aim at defending his account from a number of criticisms, mostly various versions of the luck objection against libertarians, and they deserve a careful look for those interested in this debate. As mentioned earlier, Goetz's account of the power to choose freely entails a version of PAP, and in chapter five he attempts to defend that entailment from the challenge posed by Frankfurt-style counterexamples. This chapter stands at nearly fifty pages and is the longest in the volume by a substantial margin; Goetz claims that this length is deserved since "no issue has influenced the discussion about free will more in the past thirty-five years than PAP" (p. 75). In this chapter, Goetz endorses and defends what is known as the Dilemma Defense - FSCs, once all the relevant factors are spelled out, are either such that the agent is morally responsible but still has alternative possibilities, or beg the question against the incompatibilist by presupposing the truth of determinism. Goetz's treatment of this issue is as thorough as one will find in the current literature, engaging FSCs presented not only by Frankfurt, but also by Stump, Mele and Robb, Fischer, McKenna, Haji and McKenna, Pereboom, and Hunt. Goetz builds on earlier versions of the Dilemma Defense proposed by Robert Kane and David Widerker. But then Goetz finds himself in "awkward position of defending PAP against [David] Widerker himself" given that Widerker "has had a change of mind and believes it is possible to construct two successful FSCs against PAP" (p. 113).

In the final chapter of the book, Goetz weaves together a number of issues: the relationship between free will and happiness, restrictivism, life plans, and the problem of evil. As with the middle chapters, there is substantially more content than I can address in this review. For example, he argues at length that the theistic philosopher ought not be content with a mere defense, but rather needs to engage in theodicy in responding to the problem of moral evil. (With respect to the problem of animal suffering, Goetz thinks that a defense is sufficient. For the reasons behind this asymmetry, see pp. 152ff.) Goetz works to provide just such a theodicy based on the experience of complete happiness and the defeat of evil. Rather than exploring this line of argumentation in greater 
detail, however, I want to end by focusing on the connection between the account of free will that Goetz develops earlier and his treatment of theism and the problem of evil in this chapter. In the introduction, Goetz considers some comments by Manuel Vargas about the correlation between libertarianism and theism (a correlation which has been confirmed by the recent PhilPapers study conducted by David Bourget and David Chalmers). In response to Vargas, Goetz claims that "I do not espouse libertarianism because of my religion. Rather, I espouse my religion because I am a libertarian. I am inclined to think that there is a supreme agent who acts for purposes because I am aware that I am an irreducible, substantive agent who acts for purposes" (p. 7). And while Goetz goes a considerable distance, via his proposed theodicy, in showing that God has a morally justifying reason for allowing the existence of moral evil, he does not show how his account of free will gives reason to believe in God, as these comments from the introduction would suggest. What he instead gives is a defensive move in that it defeats a reason for not believing in such a being, rather than giving reason to believe that there is such a being. If Goetz does believe that the existence of noncausal teleological freedom gives positive reason for belief in the existence of God, this would be a very interesting argument.

Though I've indicated a few places where I wish Goetz would have provided some supplemental argumentation, the book as a whole is rich in careful analysis and argument, particularly as it relates to the problem(s) of luck, the Dilemma Defense, FSCs, and the need for theodicy rather than mere defense. Those interested in these issues would be very well served by a careful reading of Goetz's text. 